\title{
Biocontrol of Seedling Blight Disease of Corchorus Olitorius (Jute) Using Some Fungal and Bacterial Species Isolated From Poultry Droppings and Goat Dung
}

\author{
Habiba, M. Muhammed ${ }^{1}$, Mathew,O.Adebola, ${ }^{2}$ Garba, H. Danladi, ${ }^{3}$ Maryam, Yusuf $^{1}$
}

\begin{abstract}
Compost-inhabiting microorganisms were studied for their effect on seedling blight inducing microbes on Corchorus olitorius. The fungal and bacterial species were isolated using pour plate and serial dilution methods respectively and identified based on their morphological/biochemical characteritics. Aspergillus flavus, Aspergillus niger, Bacillus cereus and Mucor were the microbes found associated with goat dung and poultry droppings compost. The population of compost inhibiting microbes was found to be higher in goat dung $6.5 \times 10^{5} \mathrm{cfu} / \mathrm{g}$ compared to poultry droppings $4.5 \times 10^{5}$ $\mathrm{cfu} / \mathrm{g}$. Aspergillus fumigatus, Penicillium notatum, Penicillium chrysogenium, and Trychophytum rubrum were isolated from blighted Corchorus olitorius seedlings. The zone of inhibition of mycelia growth of Aspergillus fumigatus, Penicillium notatum, Penicillium chrysogenium, and Trychophytum rubrum induced by $A$. flavus ranges between $10.5 \pm 0.11$ to $17.5 \pm 0.20 \mathrm{~mm}$, while Bacillus cereus has the highest zone of inhibition which ranges from $20.7 \pm 1.77$ to $16.5 \pm 1.13 \mathrm{~mm}$. The inhibitory activities of the compostinhabiting microbes might partly be responsible for the efficacy of compost in reducing seedling blight diseases in Corchorus olitorius. Goat dung and poultry droppings compost-inhabiting microbes had inhibitory effects on the seedling blight inducing microbes of Corchorus olitorius seedlings and hence can be employed as a biocontrol agent against seedling blight disease.
\end{abstract}

Keywords- Corchorus olitorius, goat dung, poultry droppings, seedling blight disease.

\section{INTRODUCTION}

C orchorus olitorius is a long soft, shiny vegetable fibre that can be spun into coarse, strong threads. It is commonly called jute and it is called Ewedu in Yoruba, Ayoyo in Hausa[26]. Corchorus olitorius called Jews mallow or jute in English is popular as vegetable in either dry or semi arid regions and in the humid areas of Africa. The plant is also known for its fibre product, [19]. It belongs to the family Tiliaceae, growing to $3.5 \mathrm{~m}$ at a fast rate. The plant is tall, usually annual herbs, reaching a height of $2-4 \mathrm{~m}$, unbranched or with only a few side

Habiba, M. Muhammed is with the Department of Biology Ibrahim Badamasi Babangida University Lapai, Niger State, Nigeria.

Mathew,O.Adebola is with the Department of Biological sciences Federal University of Techonology, Minna, Niger State, Nigeria .

Garba, H. Danladi is with the Department of Biological Sciences Kebbi State University of Science and Technology Aleiro, Kebbi State, Nigeria. branches. The leaves are alternate, simple, lancelate, $5-15 \mathrm{~cm}$ long, with an acuminate tip and a finely serrated or lobed margin. The flowers are small $(2-3 \mathrm{~cm}$ diameter) and yellow with five petals; the fruit is a many- seeded capsule. It thrives almost anywhere, and can be grown year round. The plant prefers sandy, loamy and clay soils. The vegetable does well in acid, neutral and basic (alkaline) soils[27].

Corchorus olitorius is used as vegetable in either dry or fresh in semi arid regions and in humid areas of Africa. It is also known for its fibre product[19]. It contains high levels of iron and foliate which are useful for the prevention of anemia [16]. The leaves are rich sources of potassium, iron, copper, manganese and zinc as well as high energy values essential in human and animal nutrition. The crop is an excellent source of vitamins $\mathrm{A}$ and $\mathrm{C}$, fiber, minerals including calcium and iron and other micronutrients. Corchorus olitorius leaf is extensively consumed as a "healthy vegetable in Japan, because it contains abundant carotenoids, vitamin B1,B2, C and $\mathrm{E}$, and minerals.

One of the major problems of C.olitorius is seedling blight is an infection that causes the seed or seedling to rot and die. It can be characterized by patches in the field that fail to germinate. If the seedlings do manage to germinate, they may not emerge, or they may emerge and then become brown, pinched, and die [12].

According to [11] seedling blight, or damping off is a disease complex caused by several seed-borne and soil-borne fungi, including species of Cochiobolus, Curvularia, Fusarium, Rhizoctonia species and Sclerotium. These organisms are activated by the presence of the plant and the substances released by its roots. These pathogenic organisms invade the root directly or through wounds and move into the cortical tissues or into the vascular system. They release enzymes which degrade the seedling tissue and distrupt normal plant growth processes. If the conditions are favourable, the result is poor germination and poor emergence. Seedlings often die after emergence, but the most vulnerable period is from germination to emergence[28]. Symptoms of seed infection include failure to germinate, becoming soft, turning brown, eventually shrinking and disintegrating. The infection of seedlings under the soil, before emergence is dark and water soaked. The infected area enlarges invade cells, collapse and the seedling die shortly after, without emerging. Seedlings that have already emerged are attacked at the roots and the stem at 
the soil line or below [29]. Seedling blight of C.olitorius have been previously done using fungicides control. However, chemical control of this disease is not cost-effective coupled with the obvious environmental harzards. Biological control being relatively cheaper, less laborious and environmentally friendly becomes an attractive option[25]. Thefore, this study was carried out to control Corchorus olitorius seedling blight disease using fungal and bacterial species isolated from organic composts (poultry droppings and goat dung).

\section{MATERIALS AND METHODS}

Collection of samples and raising of Corchorius olitorius seeds: Poultry droppings and goat dung were collected and put inside polythene bags and labeled from the Agricultural research farm of the Department of Agriculture Ibrahim Badamasi Babangida University Lapai Niger State Nigeria. Corchorius olitorius rhizosphere and rhizoplane that showed the symptoms of seedling blight disease in farmer's field were collected and stored in sterile dry paper bags at ambient temperature. Seeds of $C$. olitorius were procured from ten farmers in Lapai, Lapai Local Government Area Niger State Nigeria after harvesting period in August, 2014. Three (3) seeds were sowed per pots in sterile top soil in triplicates and raised to seedling stage prior to inoculation.

Isolation of the pathogen and Test organisms: Infected leaves, stems and roots of $C$. olitorius were cut into small pieces, surface-sterilized for 3 minutes with sodium hypochlorite and rinsed twice with sterilized distilled water. They were then placed on Potato dextrose agar (PDA) and incubated at room temperature $\left(28 \pm 2^{0} \mathrm{C}\right)$ for 7 days, to allow for the growth of all associated organisms [22, 3a]. Colonies observed were sub cultured on PDA to obtain pure cultures. The various fungal isolates from each of the samples were subcultured on PDA to obtain pure cultures for identification. The cultural features of each fungal isolate were carefully observed and recorded. The macro-morphological and micromorphological features of the fungal isolates were compared with those described in mycological guide [6]. One gram of poultry dropping and goat dung placed in $9 \mathrm{ml}$ of sterile distilled water in test tube and then serially diluted and $10^{-4}$ $10^{-5} 10^{-6}$ was used as the dilution factor from which $1 \mathrm{ml}$ of the diluents was placed on PDA. The plates were incubated for 6 days at $28^{\circ} \mathrm{C}$ and the microbes were identified as described above.

Screening the isolates for antagonism(Dual-culture technique): Inhibition of pathogen growth by the test antagonists was carried on PDA using the dual culture technique. Five millimeter diameter mycelia plugs of each test antagonist were placed at the periphery of three different culture plates and incubated for 2 days at $28 \pm 2^{\circ} \mathrm{C}$. After two days each plate was doubly-inoculated with another $5 \mathrm{~mm}$ diameter mycelia plug of the pathogen placed $5 \mathrm{~cm}$ from the test antagonist. The dual cuture plates were incubated for additional 9 days at $28 \pm 2^{\circ} \mathrm{C}$. In the control experiment, the test antagonists were replaced with sterile agar plugs. The growth of the pathogen in both the test and control experiment was recorded. Data were obtained for the percentage inhibition of radial growth $(100 \times(\mathrm{R} 1-\mathrm{R} 2) / \mathrm{R} 1-$ where $\mathrm{R} 1=$ radial growth of the pathogen in control and R2=radial growth of the pathogen in dual culture withantagonist) and the width of the zone of inhibition (Z1) ( measured as the smallest distance between the colonies in the dual culture). Results are means of three replicates[3a].

Test of pathogenicity of the isolates: Fungal isolates from the rhiphospere and rhizoplane of blighted Corchorus olitorius were re-inoculated into healthy four week old seedlings growing in the Screen house of the Department of Biology Ibrahim Badamasi Babangida University Lapai ( $9^{0} 3^{\prime} 0^{\prime}$ 'N latitude, $6^{0} 34^{\prime} 0^{\prime \prime}$ E longitude). A $10^{-6}$ conidia $/ \mathrm{ml}$ spore concerntration was prepared in accordance to the method [4], and sprayed on healthy Corchorus olitorius seedlings with the aid of a Hill hand sprayer [17]. The leaves, stem and root were observed for leaf wilting, brownish spots, stem collapsed and seedling death. The fungal species were re-isolated and compared with the initial isolates to confirm their pathogenicity.

Statistical Analysis: Statistical analysis [ANOVA] are performed to test the significant effects of the antagonists and means compared using the Duncan's multiple range rest at $\mathrm{P} \leq$ 0.05 .

\section{RESULTS AND DISCUSSION}

The results of microscopic observation and physical characteristic features of the isolated fungal species from seedling blight diseased Corchorus olitorius was presented in table 1.A total of four fungal species were isolated belonging to three genera. The isolated fungal species include Aspergillus fumigatus, Penicillium notatum, Penicillium chrysogenium, and Trichophyton rubrum were found to be associated with blighted seedlings of Corchorus olitorius.

Goat dung and poultry droppings inhabiting microbes isolated. Fig. 1 represents the fungal and bacterial species is( Aspergillus flavus, Aspergillus niger, Bacillus cereus and Mucor species) isolated from goat dung and poultry droppings. The population of compost inhibiting microbes was found to be higher in goat dung compare to poultry droppings. The occurrence of Mucor species range between $6.3 \times 10^{5} \mathrm{cfu} / \mathrm{g}$ in goat dung to $4.5 \times 10^{5} \mathrm{cfu} / \mathrm{g}$ in poultry droppings was the highest compare to other microbes. Aspergillus niger has the lowest occurence which range from $2.2 \times 10^{5} \mathrm{cfu} / \mathrm{g}$ in poultry dropping to $2.4 \times 10^{5} \mathrm{cfu} / \mathrm{g}$ in goat dung. The population of Bacillus cereus range from $4.1 \times 10^{5} \mathrm{cfu} / \mathrm{g}$ in poultry droppings to $5.6 \times 10^{5} \mathrm{cfu} / \mathrm{g}$ in goat dung, while the occurence of Aspergillus flavus range from $3.5 \times 10^{5} \mathrm{cfu} / \mathrm{g}$ in poultry dropping to 3.8 level of cfu/g in goat dung.

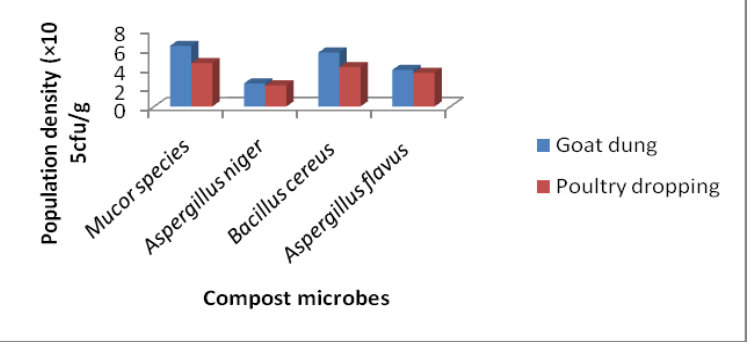

Fig.1 Mean population density of goat dung and poultry dropping inhabiting microbes. 
The results of pathogenicity done revealed that out of four fungi isolated from blighted Corchorus olitorius re-inoculated into healthy,were Aspergillus fumigatus, Penicillium notatum, and Penicillium chrysogenium produced symptoms of blight disease while the Tricophyton rubrum did not produce the symptom. Disease severity was generally high in seedlings inoculated with Penicillium chrysogenium (70\%) and Aspergillus fumigatus (80\%).

The results revealed that all potential antagonists isolated from the composts exhibited high antagonistic activities against the pathogens of C.olitorius blight [table 2]. The radial growth of the blight pathogens was retarded significantly. Bacillus cereus was the most effective, producing the widest zone of inhibition [20.7 \pm 1.77 ] against Aspergillus fumigatus followed by A.flavus and A. niger while Mucor species was least effective producing the lowest zone of inhibition [8.86 \pm 0.01$]$ against Trycophyton rubrum. The zone of inhibition produced by Penecillium chrsogenium [10.5 \pm $0.11 \mathrm{~mm}]$ and Tricophyton rubrum $[12.2 \pm 0.10 \mathrm{~mm}]$ when paired with A.flavus were not significantly different $[\mathrm{P} \geq 0.05]$

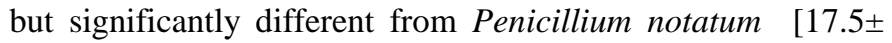
$0.20 \mathrm{~mm}]$ and Aspergillus fumigatus $[14.6 \pm 0.01 \mathrm{~mm}]$. However, the zone of inhibition produced when Bacillus cereus was separately paired with $P$. notatum, $P$. chrysogenium and Aspergillus fumigatus $[20.5 \pm 0.10$, $20.1 \pm 0.11$ and $20.7 \pm 1.77$ respectively] were not significantlydifferent $[\mathrm{P} \geq 0.05]$ but significantly different from Trycophyton rubrum $[16.5 \pm 0.12 \mathrm{~mm}]$. The zone of inhibition of $P$. notatum and $P$. chrysogenium were not significantly different when they were challenged with A.niger [17.7 \pm 1.12 and $17.3 \pm 1.02$ respectively]. When Mucor species paired with the pathogens, the zone of inhibition produced by $P$. notatum, was the highest $[13.5 \pm 1.13 \mathrm{~mm}]$ and significantly different from other pathogens.

TABLE I

Fungal SPECIES Isolated From SEEDling BLIGHT Diseased CoRCHORUS OLITORIUS

\begin{tabular}{ll}
\hline Fungal Isolates \\
\hline Aspergillus Fumigatus \\
Penicillium Notatum \\
Penicillium Chrysogenium \\
Trichophyton Rubrum \\
\hline
\end{tabular}

TABLE II

Zone Of Growth Inhibition [Mm] Induced By Poultry Dropping And Goat Dung Compost Inhibiting Microorganism On Corchorus Olitorius SEEDling Inducing PATHOGENS.

Poultry dropping and goat dung inhabiting microbes Zone of growth inhibition(mm)

\begin{tabular}{|c|c|c|c|c|}
\hline Seedling blight inducing microbes & A. Flavus & B. Cereus & A. Niger & Mucor. species \\
\hline Renicillium notatum & $17.5 \pm 0.20 \mathrm{c}$ & $20.5 \pm 0.10 \mathrm{~b}$ & $17.7 \pm 1.12 \mathrm{c}$ & $13.5 \pm 1.13 \mathrm{~d}$ \\
\hline Penicillium shrysogenum. & $10.5 \pm 0.11 \mathrm{a}$ & $20.1 \pm 0.11 \mathrm{~b}$ & $17.3 \pm 1.02 \mathrm{c}$ & $12.5 \pm 1.02 \mathrm{c}$ \\
\hline Aspergillus fumigatus. & $14.6 \pm 0.01 \mathrm{~b}$ & $20.7 \pm 1.77 \mathrm{~b}$ & $11.7 \pm 0.08 b$ & $10.2 \pm 0.23 b$ \\
\hline Trucophyton rubrum & $12.2 \pm 0.10 \mathrm{a}$ & $16.5 \pm 1.13 \mathrm{a}$ & $10.1 \pm 0.00 \mathrm{a}$ & $8.86 \pm 0.01 \mathrm{a}$ \\
\hline
\end{tabular}

Values are means \pm standard error, values followed by the same alphabets on the column do not statistically differ at [P $\geq 0.05]$ tested by Duncan multiple range test.

Seedling blight diseases of agricultural crops have remained very serious constraints to vegetable production in Nigeria. Apart from having a wide host range, most of the fungal microbes produces scleroria that remain viable in soils for many years [14].

In the present study Aspergillus fumigatus, Penicillium notatum, and $P$. chrysogenium were found to be fungal species causing blighted seedling of Corchorus olitorius except Trichophyton rubrum. This implies that T. rubrum is not a causative organism of seedling blight of C.olitorius. Prrobably it is an opportunist or secondary pathogen. The disease severity was generally high in those seedlings inoculated with $P$. chrysogenium [70\%] and Aspergillus fumigatus[80\%]. Aspergillus flavus, A. niger,Bacillus cereus and Mucor species were the four microorganisms isolated from composts for the biological control of blight fungi. This effort in finding biological control was in line with [24] who had suggested that effort and expense in finding novel biological control species and strains can be saved by directing the search either by exploration for new strains in native area of the host or its pathogen or by studying the species that are known to be phlogenetically related to species that is effective in biological control. [5] reported that soils inoculated with B. cereus, B. subtilis and Trichoderma species reduced seedling infection and that the efficacy of the antagonist increase with increase in dose lytic enzymes are known to produced by B. cereus [9]. Growth of Macrophomina phaseolina was found to be inhibited by $T$. harzanium, T. virens, A. niger, A. fumigatus, $P$. notatum, $B$ cereus and $B$ subtilis. Similar results have being reported by [20]. This finding is supported by lower inhibition zone of compost inhabitating microbes against Penicillium chrysogenium and Aspergillus fumigatus as compared with Trycophyton rubrum.

Over the past one hundred years, research has repeatedly demonstrated that phylogenetically diverse microbes can act as natural antagonists of various plant microbes [8]. The interactions between microorganisms and plant hosts can be complex. Interactions that lead to biocontrol can include antibiosis, competition, induction of host resistance, and predation [7]. When testing fungal isolates from the environment for biocontrol activities, between 1 and $10 \%$ show at least some capacity to inhibit the growth of microbes in vitro. However, fewer isolates can suppress plant diseases 
under diverse growing conditions and fewer still have broad spectrum activity against multiple microbesic taxa. Nonetheless, intensive screens have yielded numerous candidate organisms for commercial development [1]. The compost extracts contain antagonistic micro organisms and active antifungal compounds [10] which cause significant reduction in mycelial growth of the microbes.

Among the isolates tested, B. cereus was more effective against all the seedling blight inducing microbes. This is perhaps due to production of sufficient biocontrol compounds and suppressive agents against the microbes [18].

According to the report of [5] soils inoculated with B. subtilis, B. cereus and Trichoderma spp reduced seedling infection and that the efficacy of antagonists increased with increase in dose Lytic enzymes are known to be produced by $B$. cereus. Both substances, produced by $B$. cereus, may have been responsible for inhibiting the growth of the microbes observed in the study and may probably playing an important role in the prevention of seedling blight diseases [14].

Two mechanisms has been suggested to be involve in antagonistic effect of $B$. cereus. The first mechanism involve the production of biologically active compound, which inhibited the growth of the microbes. The second mechanism involve rapid growth and spread on moist surfaced agar plates, which prevented the establishment of the microbes. A lytic factor has been reported to be located in walls of strains of $B$. subtilis [23], suggesting that this might have diffused out into the surrounding medium, causing the zones of inhibition observed. Also B. subtilis has been reported of having the ability to produces at least five antibiotics namely subtilin, bacitracin, bacillin, subtenolin and Bacilomycin [2]. These substances might have acted in concert to inhibit the growth of the microbes used in this study. The least reduction of the fungal growth was achieved by the A. niger and A. flavus, this may be attributed to low biocontrol agents [13].

\section{ACKNOWLEDGMENT}

We are grateful to the entire staffs of the Laboratory of Biology Department, Ibrahim Badamasi Babangida University, Lapai, Niger State, Nigeria for providing technical assistance. We also acknowledge the financial assistance receive from the management of Ibrahim Badamasi Babangida University for sponsoring this research.

\section{REFERENCES}

[1] P. A. Abbasi, J. Al-Dahmani, F. Sahin, H. A. J. Hoitink,and S. A. Miller,. 'Effect of compost amendments on disease severity and yield of tomato in conventional and organic production systems. "Plant Disease. 2002 86:156-161 http://dx.doi.org/10.1094/PDIS.2002.86.2.156

[2] M.K. Abo-El-Dahab, and M.A. El-Goorani, 'Antagonistic effect of a Bacillus strain upon Erwinia amylovora”.' Phytopathology 1974. 64: 285- 286

[3] M.O Adebola and J.E Amadi "Antagonistic activities of Paecilomyces and Rhizopus species against the cocoa black pod pathogen (Phytophthora palmivora)". African Scientist 2010. Vol. 11:1-5.

[4] K.P., Akhtar, M., Matin, , H., Mirzaj A.S Shakir, and M. Rafique." Some studies on the post-harvest diseases of tomato fruits and their chemical control'". Pakistan Journal of Phytopathology 2004..6: 125-9.

[5] S.A. Bankole, and, A. Adebanjo." Efficacy of some fungal and bacterial isolates in controlling wet rot disease of cowpea caused by Pythium aphanidermatum." Journal Plant Protect Tropics 1998. 11: $37-43$.

[6] H.L Barnett and B.B Hunter. Ilustrated genera of imperfect fungi. Burgess Publishing Company Minnesota 1996.

[7] L. R. III Bulluck,, and J. B. Ristaino,. ' 'Effect of synthetic and organic fertility amendments on southern blight, soil microbial communities, and yield of processing tomatoes". Phytopathology . 2002 . 92:181189. http://dx.doi.org/10.1094/PHYTO.2002.92.2.181

[8] R. J. Cook. "Advances in plant health management in the 20th century". Annual. Review. Phytopathology, 2000. 38:95-116. http://dx.doi.org/10.1146/annurev.phyto.38.1.95

[9] S. Csuzi. "The induction of a lytic enzyme in cultures of Bacillus cereus Acta" Biochemistry Biophysic Academic. Science. Hung. 1978 13: 41-42.

[10] M.H., El-Masry, A.J., Khalil, , M.S. Hassouna and H.A.H. Ibrahim. 'In situ and in vitro suppressive effect of agricultural composts and their water extracts on some phytopathogenic fungi". World Journal of Microbiology and Biochemistry 2002. 18:551 - 558 . http://dx.doi.org/10.1023/A:1016302729218

[11] D. Groth,and C. Hollier "'Seedling blight of rice" Louisiana plant pathology. Disease identification and management series, Louisiana University press Louisana 2010 pp1-9..

[12] B. Karla. "Seedling blight frequently asked question". Agricultural information center. Agriculture and rural development .Alberta press. Alberta 2003.

[13] A. Kerkeni, , M., Daami-Remadi, N. Tarchoun and, M. Ben-Khadeer. "In vivo assessment of the antifungal activities of several compost extracts obtained from composted animal manure mixtures". International Journal of Agricultural Research 2007. 2: 786 - 794. http://dx.doi.org/10.3923/ijar.2007.786.794

[14] S. Muhammad and N. A. Amusa "In-vitro inhibition of growth of some seedling blight inducing pathogens by compost-inhabiting microbes". African Journal of Biotechnology 2003. 2(6), 161-169. http://dx.doi.org/10.5897/AJB2003.000-1033

[15] H.M. Muhammed, and S. Muhammad. 'Invitro inhibition of growth of Aspergilus niger, Fusarium oxysporum and Rhizopus nigricans by antagonistic microorganisms isolated from composted wastes'. Journal of Phytopathology and plant health. 2013. 2: 83-90.

[16] D.J., Oyedele C. Asonugho, and O.O. Awoloye. 'Heavy metals in soil and accumulated by Edible Vegetable after Phosphate fertilizer application'. Electron Journal of Agricultural Food Chemistry, 2006. 5(4): $1446-1453$.

[17] R.N Okigbo and F.E.O Ikediugwu,. "'Studies on biological control of post harvest rot of yams (discorea species) with Trichoderma viride". Journal of Phytopathology. 2000. 148: 351-355. http://dx.doi.org/10.1111/j.1439-0434.2000.tb04786.x

[18] W. Quarles,. "Compost tea for organic farming and gardening'. The IPM Practitioner. 2001. 23(9), 1 - 8.

[19] R.R. Schippers, . 'African Indegenous vegetables. An over view of the cultivated species". chathman, U.K., Natural Resource institute/ACPEU. Technical center for Agricultural and Rural Co operation 2000. pp. 214

[20] M, Schrettl E, Bignell C, Kragl Y, Sabiha O, Loss M. Eisendle. "Distinct Roles for Intra- and Extracellular Siderophores during Aspergillus fumigatus Infection". PLoS Pathology 2007. 3(9), 1195207. http://dx.doi.org/10.1371/journal.ppat.0030128

[21] G. Sharma,and R.R. Pandey..Influence of culture media on growth, colony character and sporulation of fungi isolated from decaying vegetable wastes, Journal of Yeast and Fungal Research, 2010. 1(8), 157-164

[22] P.R. Tondje Berry, K.P., G., Hebber, J.H., Samuels, Bowers, S., Weise, Nyemb, E. Begonde, D., J., Foko, and, D. Fontem. 'Bioassay of Geniculosporium species for Phytophthora megakarya biological control on cocoa pod husk pieces"'African Journal of Biotechnology.2006. 8: 648-652.. 
[23] F.E., Young, J. Tupper, and J.L. Strominger,. Autolysis of cell walls of Bacillus subtilis mechanism and possible relationship to competence. Journal of Biology Chemistry. 1974. 249: 3600-3602.

[24] J.G. Samuel and P. Hebbar. Tricoderma: its potential for control of diseases of cocoa. Fourteenth International Cocoa Research Conference. Pp. 669-675.

[25] M.O Adebola and J.E Amadi (b) 'Screening three Aspergillus species for antagonistic activities against the cocoa black pod organism (Phytophthora palmivora). Agricultural Biological Journal of North America 1:3: 362-365.

[26] M, Amanabo, I.S.Matthew ., Ezenwa, Johnson A. Oladiran, H. O. Akanya, and Emmanuel O. Ogbadoyi. "Effect of soil nitrogen levels on some micronutrients, antinutrients and toxic substances in Corchorus olitorius grown in Minna, Nigeria." African. Journal. Agriculture. Research 5, no. 22 (2010): 3075-3081.

[27] L. Njoku, Kelechi, O. Bola., Oboh, Modupe O. Akinola, and A. O. Ajasa. "Comparative effects of Abelmoschus esculentus (L) Moench (Okro) and Corchorus olitorius L (Jew Mallow) on soil contaminated with mixture of petroleum products." Research Journal Environment Earth Science 4, no. 4 (2012): 413-418.

[28] Z, Manman, Ye Tao, S. Hussain, Qingwei Jiang, Shaobing Peng, Jianliang Huang, Kehui Cui, and Lixiao Nie. "Seed priming in dry direct-seeded rice: consequences for emergence, seedling growth and associated metabolic events under drought stress." Plant Growth Regulation (2015): 1-12.

[29] M. N.,Khare S. P. Tiwari, and Y. K. Sharma. "Disease problems in fennel (Foeniculum vulgare Mill) and fenugreek (Trigonella foenum graceum L.) cultivation and their management for production of quality pathogen free seeds." International Journal. Seed Spices 4, no. 2 (2014): 11-17. 